\title{
Mediating Multiculturally: Culture and the Ethical Mediator
}

Carrie Menkel-Meadow

Georgetown University Law Center, meadow@law.georgetown.edu

Harold I. Abramson

Touro Law Center

Georgetown Public Law and Legal Theory Research Paper No. 12-061

This paper can be downloaded free of charge from:

https://scholarship.law.georgetown.edu/facpub/961

http://ssrn.com/abstract=2035003

Mediating Multiculturally: Culture and the Ethical Mediator, in MEDIATION ETHICS: CASES \& COMMENTARIES 305-338 (Ellen Waldman ed., San Francisco: Jossey-Bass 2011)

This open-access article is brought to you by the Georgetown Law Library. Posted with permission of the author. Follow this and additional works at: https://scholarship.law.georgetown.edu/facpub

Part of the Dispute Resolution and Arbitration Commons, and the Legal Ethics and Professional Responsibility Commons 


\section{Ellen Waldman, Editor}

\section{me Mediation Ethics}

Cases and Commentaries

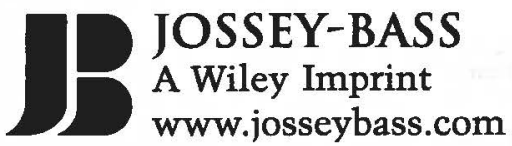




\section{Mediating Multiculturally Culture and the Ethical Mediator}

hether your mediation practice takes you on a circuit of local postal codes or globe-trotting overseas, it is likely that you will find yourself mediating with parties from a different culture. In most instances, the questions you confront will be functional and practice oriented: How do I manage the process with parties whose cultural affiliations lead them to perceive language and behavior so differently? How can I help them reach an agreement despite their culturally distinct approaches to the issues they face?

Occasionally, though, the clash of cultures will lead to ethical conundrums. Although all ethical problems are challenging because they present compelling values in ineluctable tension, cross-cultural ethical dilemmas are particularly agonizing because they seem to require a choice between deeply felt cultural traditions. Amid current heightened sensitivities attending charges of Western cultural domination, the act of choosing in this context seems particularly fraught.

Before delving into the specifics of intercultural negotiation, it is important first to clarify some fundamental terms and concepts. 
What do we mean by culture? How does culture affect negotiation? And how might intercultural mediation spawn head-scratching ethics questions?

\section{CULTURE AND DISPUTING}

Ask ten people what culture means, and you will likely get eleven answers. The term is notoriously difficult to define and takes on different shadings depending on the purposes the definition is intended to serve.

\section{A Current Definition of Culture}

In the late nineteenth century, British social critics spoke of culture when they sought to distinguish aristocratic forays into the "high arts" from the baser pursuits of the masses. Matthew Arnold, in his 1869 polemic, Culture and Anarchy, referred to culture as the "best which has been thought and known in the world." In contrast to materialistic or mechanistic concerns, he viewed culture as those endeavors that would "help men live in an atmosphere of sweetness and light ... where they may use ideas ... freely-nourished and not bound by them."2

Later definitions dropped the distinction between "high" and "low" artistic or intellectual production and sought to expand understandings of culture to include the wide variety of ways that people create, consume, and transmit meaning in the world. This capacious view of culture's dominion gained traction throughout the twentieth century and is reflected in the sweeping field of academic study termed cultural studies, which encompasses anthropology, sociology, linguistics, and semiotics. According to current understandings, culture is the "deep-grammar"3 or "mental software"4 that we use to communicate with and "decode" others.

This broad view of culture surfaces in legal definitions as well. The United Nations Educational Scientific and Cultural Organization, a body devoted to promoting diversity and multiculturalism, defines culture as "the whole complex of distinctive spiritual, material, intellectual and emotional features that characterize a society or social group. It includes not only the arts and letters, but also modes of life, the fundamental rights of the human being, value systems, traditions and beliefs." 5 
Clearly culture today encompasses all those habits of action and thought that link us to the larger communities around us. Thus, culture is not simply what we do; it is the lens through which we see the world. It not only primes our choices but shapes how we view the choices of others.

\section{Cultural Aspects of Disputing Style}

Cultural lenses tint virtually every scene we encounter. What if we are in a negotiation and a representative from the opposing firm takes off his jacket and rolls up his shirt sleeves? Do we think, "Oh, that's nice, he feels comfortable being informal with me. We must be getting somewhere." Or do we fret, "Hmmm, how disrespectful. He doesn't even think enough of me to stay business-like in his attire. I must be losing ground here." Hailing from a formal, hierarchically driven culture or from one focused less on status and more on function will shape our response to such a change in our negotiating partner's dress.

Experts in intercultural negotiation have identified a series of cultural features that influence disputing style. These features reflect different cultural conceptualizations of identity, language, and structure. If disputants bring to the mediation table dramatically differing expectations of how individuals fit into group hierarchies and communicate within and between them, mediation becomes more of a challenge. Often stylistic differences require the mediator to constantly explain, reinterpret, and reframe. In some situations, the parties' norms will be so different from both the mediator's and each other's that helping forge agreement will prove ethically problematic. Here briefly are some poles along which cultures tend to divide: ${ }^{6}$

- Sense of identity: Individualistic or collectivist? Negotiators in individualistic cultures feel less attached to social groups and more inclined to focus on personal goals and preferences. ${ }^{7}$ They are likely to view negotiation solely as a resource-distribution exercise, focusing on the end result of who gets how much and when. Negotiators in collectivist cultures view themselves as more interdependent and bound by a larger web of social relations and obligations. They place greater emphasis on the relationship-building aspect of negotiations. Decisions to compromise, hold fast, agree, object, or explain are all 
made with an eye to how decisions will affect goodwill, sympathy, and trust between the parties.

- Rules: Universalist or particularist? ${ }^{8}$ Universalist cultures (often also individualistic) believe rules should be applied consistently. Membership in a particular school, profession, family, religious institution, or ethnic group is seen as irrelevant to how rules should be understood and implemented. If a rule is fair for one group, it is fair for all. By contrast, particularists would trade uniformity for sensitivity to context. They believe members of in-groups deserve special consideration, precisely because of the relationships involved. For particularists, every situation is different, and different situations call for different rule application.

- Status and power: Low power distance or high power distance? Lowpower-distance cultures deemphasize status and hierarchy, focusing on individual performance and function. These cultures tend to promote democratic decision making; the distance between individuals at the top or the bottom of an organizational hierarchy is not viewed as justifying radically differential treatment. In high-power-distance cultures, individuals at the low end of the scale "expect and accept that power (e.g. wealth, prestige, access to education and other benefits that enhance power) [is] distributed unequally.", In these cultures, age, seniority, rank, and title figure prominently in the distribution of rewards and burdens.

- Use of language: Low context or high context? High-context cultures assume that speaker and listener share a common heritage or background and that language builds on a set of unspoken but acknowledged understandings. ${ }^{10}$ Speakers in this culture communicate indirectly through implication and suggestion, assuming that the message is partially transmitted to the recipient through a shared history and context. By contrast, speakers in low-context cultures rely on direct, concrete speech to convey meaning. They believe that the message embodied in any communication can be found exclusively in the detail and logic of the words used. That is why they stress clarity and precision.

- Structure and time: Monochronic or polychronic? Monochronic cultures (like the United States, Germany, and Northern Europe) view time as a precious resource to be guarded and preserved. In these cultures, individuals are comfortable proceeding through tasks 
in linear fashion, finishing one project before taking up another. Efficiency is highly valued and entails advance planning, agenda setting, and strict adherence to schedules. Personal needs are adjusted to fit existing work timetables. ${ }^{11}$ Polychronic cultures view time as a more flexible resource that should be subordinated to people's changing needs. In addition, projects do not necessarily proceed in lockstep fashion. Multitasking, juggling, and zigzagging between projects are acceptable approaches to managing professional obligations and the many intrusions that disrupt them.

- Attitude toward uncertainty: Low uncertainty avoidance or high uncertainty avoidance? Low-uncertainty-avoidant cultures have a higher tolerance for ambiguity and risk. This propensity creates space for innovation and experimentation. Low-uncertainty-avoidant cultures celebrate new ideas and are open to alternate approaches and deviations from the norm. Rules tend to be informally expressed, open textured, and subject to variable interpretations. High-uncertaintyavoidant cultures, on the other hand, view new or ambiguous situations with anxiety. These cultures celebrate structure, tradition, ritual, and formally expressed rules. Comfort is found in "doing things the way we've always done them."12

Although it is useful to learn to identify such traits and features that may broadly characterize a particular culture, it is also important to avoid cultural essentialism - the urge to reduce that culture and its members to one monolithic pattern. Cultural characteristics are not immutable or universal, and individuals often belong to not one national culture but a series of overlapping communities, each with its own norms and values. Family units, professional communities, religious sects, and even tightly knit recreational groups foster their own sets of expectations and understandings. An Argentinean accountant may engage in behaviors that can be identified with the larger Latino culture, but he may also follow a cultural script dictated by his family, church, accounting firm, and local soccer league. These other behaviors may be consistent or inconsistent with those traits we see as "typically South American."

When analysts speak, for example, of collectivist or high-power cultures, they are using shorthand. What they mean to say is that a higher percentage of individuals in that culture (as opposed to other 
cultures) are likely to behave pursuant to collectivist or high-power assumptions. Of course, there will be outlier individuals on either tail of the bell curve. While generally Mediterranean cultures tend to employ a more flexible, expansive view of time and deadlines, no one should go into a negotiation with a Spanish or Italian team with the expectation that previously agreed-to timetables will have no meaning. Better to view the descriptors presented above as cultural proclivities that may or may not be actualized in any given setting. Keep the information above in mind when mediating multiculturally, but do not become rigid or stereotypical in your thinking.

\section{HOW CULTURAL DIFFERENCES COMPLICATE MEDIATION}

It doesn't take much imagination to see potential challenges in mediating between two individuals from different cultures. Consider a buyer-seller dispute: pair a collectivist, high-context, high-powerdistance, high-uncertainty-avoidant buyer with an individualist, low-context, low-power-distance, low-uncertainty-avoidant seller. Their dealings may falter on linguistic misunderstandings alone.

Of course, individuals within a culture do vary, and it is dangerous to overgeneralize. Still, if we can indulge in some broad-based stereotypes, we may assume that the seller from the individualist culture (say, the United States, Germany, or some other Northern European or North American region) will be inclined to want to begin the encounter by getting down to business. She will not be shy in saying what she needs to complete this sale, and she will be aiming to memorialize the deal in a detailed document that considers all contingencies and explicitly provides for remedies if the buyer fails to perform. The buyer (say from China, Japan, or other Asian country), working with different conceptions of what a negotiation should look like, would likely be more comfortable beginning with small talk, perhaps showing the seller the sights about town and breaking bread in an informal way before beginning number-crunching in earnest. Uncomfortable with blunt self-assertion, the buyer will likely shy away from direct requests for a particular price or clear dismissal of the seller's demands. Rather, he will talk circuitously about his financial budget and other constraints. Also, he will want to frequently check back with his associates at the home office to be sure that his instincts are in sync with the rest of his department. If the seller is of 
a lower rank in her company than the buyer is in his, that may lead the buyer to view her with less respect, whereas the seller may feel that such rank differentials are irrelevant.

Differences in how buyer and seller approach language, relate to status differentials, identify as embedded in relational networks, and experience time may breed confusion and turmoil. The seller may become impatient with the buyer and conclude that his unwillingness to say yes or no to particular numbers means he's not really ready to deal. The buyer may conclude that the seller is rude and abrupt and that her obsession with discussing what will happen in the event of a breach means that she is operating in bad faith. The buyer may begin with a bias against the seller because her tenure with her company is not as lengthy as his and her position as a bargaining partner may seem to imply disrespect for his experience. Extensive rapport-building chitchat about non-deal-related topics may seem vital to the buyer, but wasteful to the seller.

\section{FOUR STEPS IN DEALING WITH CULTURAL DIFFERENCES}

Hal Abramson, an experienced cross-cultural mediator whose commentary appears later in this chapter, has suggested that mediators adopt a four-step approach to cross-cultural negotiations. ${ }^{13}$ When mediators are working with disputants from different cultures, he advises they (1) understand their own culture, (2) research the other culture, (3) bridge any cultural gap, and, when appropriate, (4) consider withdrawal. Mediators always retain the option of withdrawing if the parties' preferred outcome violates their own ethical sensibilities, and they should take that option seriously in difficult cases.

If the buyer and seller discussed above decided to pursue mediation, a mediator who worked through these steps would likely be helpful in surmounting culturally generated confusion and moving closer to an agreement.

\section{Step One: Understand One's Own Culture}

This first task involves self-interrogation. The mediator must first evaluate her own cultural expectations and biases. Continuing the buyer-seller story, for example, a North American mediator (say, from 
Manhattan) is likely to sympathize with the individualist seller. She oo might see the negotiation purely as a resource distribution exercise hat should be handled with maximal economy and parsimony. She night encourage both parties to be clear, direct, and straightforward; o share interests, needs, and bottom-line reservation points. And she night find a detailed, precise agreement preferable to a vague, openended one. But preferences are not requirements. If the mediator scrutinizes her own background, she will come to understand that uer negotiating style is heavily culturally determined. She will see that predilections for meandering versus strictly cosseted meetings, for vague versus meticulous drafting, or for formal versus informal manners of speech are equally valid choices, and that it would be improper for her to favor one cultural style over another.

\section{Step Two: Research the Other Culture}

Because in our example the buyer is from Asia, the mediator should inquire into Asian practices and gather as much information as possible about prevailing cultural norms of the area. In the course of doing this, the mediator will learn that the buyer is following a well-established cultural script and that the buyer's obliqueness and concern for what peers back at the home office say about the deal are not necessarily ploys to drive up the price. Rather, they reflect the more communal, relationship-oriented values that predominate in the buyer's homeland. Once the mediator gains a better understanding of the buyer's view of relationships, language, negotiating pace, and structure, she can function more effectively as interlocutor.

\section{Step Three: Bridge Any Cultural Gap}

At this point, the mediator can attempt to bridge the cultural divide by helping educate each party about the other's culturally driven behavior and help them approach one another with a more open and accepting mind. The mediator might explain to the impatient seller that the buyer is working with a different set of goals for the negotiation. She might help the seller see that the buyer's elliptical use of language fits into his larger notion of keeping relations harmonious. She might question the seller's assumption that the buyer doesn't 
really want to settle and explain that team negotiating is common in other areas of the world. She might ask the seller whether she might be comfortable slowing the discussions down, engaging in more purely social activity, and relying on a final document that might not be as thorough or detailed as she would ordinarily like. The mediator would also approach the buyer and talk to him about how he is interpreting the seller's abrupt response to his offers. She might explain the more task-oriented approach of North American negotiators and see if the buyer might be able to respond to the seller's need for clarity and forward movement by streamlining the process.

\section{Step Four: Consider Withdrawal}

Working with culturally diverse parties, a mediator needs to consider whether the end result comports with her own sense of ethics and professionalism. In the buyer-seller example, it would not seem that the stylistic differences presented by the North American seller and Asian buyer call the mediator's professionalism into question. It is possible that the parties' cultural differences may have so corroded trust and belief that the mediator is unable to repair the damage. Misunderstandings may have reached such a pitch that the mediator is unable to excavate common ground. But these failures implicate a mediator's skill and effectiveness, not her ethics.

In some multicultural disputes, however, the culture clash leads to ethical problems. In some cases, the question is not whether the mediator can locate common ground, but whether the ground that one or both parties insist on occupying is terrain the mediator feels comfortable sharing. What happens when a clash of cultural values leads to a potential outcome that the mediator finds ethically troublesome? Case 12.1 explores this question.

\section{CASE 12.1: HANNAH AND YOAV'S BROOKLYN DIVORCE}

Hannah and Yoav grew up in an ultra-Orthodox Jewish community in Brooklyn where arranged marriages are common. Following this tradition, they wed when they both turned eighteen. In the thirteen years since the wedding. Hannah and Yoav have followed Jewish law (the Halakhah) assiduously, observing every ritual of Orthodox Jewish life. 
As is common in this community, Yoav has not held a steady job throughout the marriage. Most of the time he can be found in shul studying the Torah. He has relied on Hannah to be the primary wage earner. In the early years of the marriage, Hannah worked as a grade-school teacher, but ten years ago, Yoav gambled away the family's savings. To boost her salary, Hannah began working for her father, who owns several nursing homes throughout the country. As a highly positioned and well-paid member of the family enterprise, Hannah was required to travel extensively and was exposed to a more secular world. Over time, she found herself questioning many of the practices of her community and found herself attracted to a life less circumscribed by religious rules and mores. At the same time, Yoav proved himself unwilling to confront and manage his gambling addiction. When Hannah sought help from the neighborhood rabbi, he simply told her to pray to God and continue being a "good wife."

Disillusioned with her community and despairing of her marriage, Hannah asked her husband for a divorce. He refused. Jewish law provides that only the husband may initiate a divorce. The husband alone is authorized to grant a get, the certificate that ends the marriage. ${ }^{14}$ If a husband withholds his consent, his wife is considered still bound to him by Jewish law. She cannot remarry, and any children she might bear in a subsequent marriage would be considered mamzerim (literally, bastards) and heavily stigmatized. A woman whose husband refuses to deliver a get is known as an agunah, "a chained woman."

Hannah does not want a huge fight with Yoav and would like to obtain a get through mediation, if that is possible. Although she feels alienated from the ultraOrthodox community and feels certain she will not return, she does not want to stigmatize or taint the prospects of any future children she might have. In addition, she appreciates her parents' support and does not want to damage them further among their peers. Pursuing a secular rather than Jewish divorce would heighten the scandal. Yet she is sufficiently offended by Yoav's recalcitrance and the unhelpfulness of the rabbis that a secular divorce remains very much on the table. Hannah has consulted an attorney and has learned a bit about how divorces are obtained in New York family courts.

Yoav is furious and afraid. He has never supported himself. He says the only way he will grant Hannah a get is if she promises to give him $\$ 500,000$, which is almost the entire amount that Hannah has saved by working with her father and scrimping on personal expenses over the past decade. Hannah feels the request is extortionate. She worked hard for that money and does not believe Yoav contributed anything positive to the marriage. She is willing to give him some money, but not the entire amount. When she learns that a secular court would not award him more than $\$ 250,000$, she names that number as her walkaway point. 
In mediation Yoav makes the case that any future children Hannah might have will never be able to have a "Jewish life" because of her selfish decision to pursue a civil divorce. Hannah is entirely unsure if she will have children, but the argument has some force with her. She has authorized you to offer Yoav $\$ 375,000-50$ percent more than he would be entitled to in a New York family court. You believe that Yoav will probably take it.

Do you go forward facilitating this agreement?

Before proceeding, it is first necessary to clarify in what sense this is a multicultural dispute and consider what ethical issues are raised.

\section{Jewish Orthodoxy Versus Secular Culture}

We can consider this a multicultural dispute because Yoav is negotiating solely within the confines of Orthodox Jewish culture, whereas Hannah has only one foot in that world. Increasingly, she has begun to locate her values, expectations, and goals in the secular world.

Ultra-Orthodox Jewry and secular culture are different in many ways. Most important for our purposes, they differ regarding gender roles and equality between the sexes. Obviously these differences figure prominently in Hannah and Yoav's notion of what constitutes a fair and correct division of property in the wake of divorce.

According to ultra-Orthodox tenets, men and women possess different intellectual, emotional, and spiritual capacities that incline them toward different life tasks. Women are thought to be particularly well suited to domestic activities, whereas men are thought to be naturally predisposed toward spiritual pursuits. Education in those Jewish communities is sex segregated, designed to prepare women to raise children within the faith and keep a kosher home, while men are trained for a life of Torah study. ${ }^{15}$

A primarily patriarchal ordering of rights and responsibilities finds expression in the Halachic rules governing marriage and divorce. In granting husbands unilateral control over divorce, Jewish law gives men an invaluable bargaining chip and an almost insurmountable advantage at the negotiating table. ${ }^{16}$ Secular liberal democracies are founded on different assumptions that grant men and women equal status (at least theoretically) in the public as well as private sphere.

The culture clash here relates both to power distance and gender roles. Ultra-Orthodox Jewish culture can be viewed, at least in the 
matter of divorce, as a high-power-distance culture in which both women and men accept that power is distributed unequally by gender. The culture of most secular liberal democracies adopts a lower-power-distance approach to marriage and divorce in insisting that men and women enjoy equal power to enter into and dissolve their marriages.

\section{Self-Identification with Different Cultures}

Yoav is immersed in and accepts the cultural values of his Orthodox Jewish community, including the male prerogative to exercise and exploit the unilateral power to divorce. Hannah has rejected these cultural values and has adopted a lower-power-distance approach. Her cultural alignment is with the larger secular community where her professional interactions occur.

The ethical issue for the mediator arises because Hannah is considering entering into a settlement that affords her a smaller percentage of the marital pie than would a secular court. Yoav is using the power conferred on him by Orthodox Jewish law and tradition to extract a more favorable postdivorce settlement than would be his due were the case decided by a New York judge. Is this use of Orthodox patriarchy in the mediation problematic? Is Hannah being disadvantaged in a way that the mediator should not condone? Is the outcome here one that the mediator should repudiate by speaking out against it or terminating the mediation?

\section{Validating Hannah's Choice}

Although reasonable people could differ on this point, a strong argument can be made that the mediator should feel ethically comfortable helping Yoav and Hannah settle, even if Yoav is walking away with 75 percent of the marital assets.

Why is this? First, it is important to remember that one of the primary advantages of mediation is that disputants can conclude their disputes according to their own values, norms, and preferences and not anyone else's. So if a disputant chooses to give more or accept less than a judge, legislator, arbitrator, or anyone else might deem prudent, that is her right and privilege. Of course, if the agreement is too one-sided, a mediator may, and should, worry about whether fear, despair, or ignorance is driving the willingness to settle for what others would see as a bad deal. And when dealing 
with cultural differences, it is important to consider whether cultural norms so disable one party as to render negotiations dangerous. In that situation, a mediator may want to think about withdrawing or recommending that the disempowered party seek assistance or information from a support person.

As we have seen, cultural norms support some behaviors and demonize others. In addition, as in Yoav and Hannah's case, they offer substantive bargaining chips to some individuals and withhold them from others. In light of the advantages that cultural norms can confer, mediators are well advised to consider whether the bargaining table is too tipped in one party's favor to yield an ethically acceptable outcome.

Here, for a variety of reasons, the mediator may view Hannah's choice as sufficiently free and self-determining that the mediator should feel comfortable proceeding. First, Hannah does not feel confined by the ultra-Orthodox rules governing divorce. She has already made a choice to step out of that community and live her life according to a different set of standards. For this reason, she enjoys a certain liberty of choice. She can choose to bargain with Yoav regarding his consent to the Jewish divorce, or she can pursue a secular divorce in the New York courts. She has a variety of options, and each is real and viable.

Pursuing a Jewish divorce holds certain advantages for her; it will remove the possibility of exclusion and stigma for any future children she may have and spare her parents unnecessary embarrassment. But Yoav's consent will cost her an additional $\$ 125,000$. Hannah appears to be a strong, capable, well-informed negotiator. She understands the entitlements that secular law would confer and understands the costs of pursuing them. She is well positioned to determine whether the personal advantages that obtaining a Jewish divorce confers are worth the additional money she will need to pay. If she chooses to pay it, she will still be financially stable and can look forward to rebuilding her nest egg using her existing skill set.

\section{Finding Balance}

Taken too far, the notion that "parties should be able to do what they want in mediation" has the potential to yield monstrously unfair outcomes. Although we should be wary of imposing our cultural norms on others, most of us would draw a line at outcomes that seem 
(to our admittedly Western, democratic eyes) abusive or exploitative. Whereas a purely relativistic stance renounces universal standards of right and wrong, a less extreme view maintains that it is possible to embrace and reject cultural practices pursuant to a consistently applied set of standards and principles.

In sum, mediating multicultural disputes forces mediators to confront the twin dangers of cultural imperialism and cultural relativism. Taken too far, either stance can cause harm. Refusing to work with disputants because of their culturally determined norms communicates that those norms, and the culture that produced them, are inferior. This message undercuts the values of tolerance and inclusion to which the dispute resolution field aspires. On the other hand, viewing any cultural practice as permissible simply because it has gained acceptance in some part of the world may place vulnerable disputants in jeopardy and violate individual mediators' cherished moral commitments.

It is important to find some balance between a cultural provincialism that finds fault in difference and a radical relativism that insulates from ethical judgment all culturally driven practices. In Yoav and Hannah's case, the liberty Hannah enjoys to choose between cultural norms and evaluate the benefits she can derive from each makes the mediator's balancing act easier. The mediator can affirm Hannah's financial sacrifice without worrying that she has fallen into a trap set for her by a culture unsympathetic to female autonomy and agency. But what if, due to the disputants' cultural affiliations, the choices are more constraining?

In the next case, starker options make finding the balance more difficult.

\section{CASE 12.2: ZIBA AND AHMED'S IRANIAN-AMERICAN DIVORCE}

Seventeen-year-old Ziba and her forty-four-year-old husband Ahmed have come to you for mediation services. Ziba and Ahmed have been married for four years. They have two sons, ages three and two. Ziba wants a divorce, but, like her husband, is anxious to remain part of the local mosque and surrounding community. In order to ensure that the divorce is handled in accord with Quranic principles and meets the approval of their peers and community elders, Ziba and Ahmed met with their imam to learn how their marriage contract may be properly resolved in accord with local interpretations of Islamic law. 
Their imam advised them that while a husband can ask for and obtain a divorce for any reason, he is obliged to support his children until they reach the age of majority, regardless of who has primary custody. If the wife remains in the husband's home to observe a mandatory waiting period of seclusion, then he must provide for her needs during that time. In addition he is obliged to pay the amount stipulated in the marriage contract that must be paid if the marriage comes to an end. Ziba and Ahmed's marriage contract calls for a payment of forty thousand dollars.

The imam also tells Ziba that she cannot receive a divorce without Ahmed's consent. And if she initiates the divorce, she will lose her right to the marriage contract payment, although Ahmed's financial obligations toward the children still stand. As far as custody of the children goes, local understandings of Islamic law presume that young children should stay with their mother, but that once sons reach their seventh birthday, custody reverts to the father. ${ }^{17}$

Ziba is miserable in the marriage. Ahmed is controlling and rigid in his notions of what Ziba can do. He monitors her movements, allowing her outside only to shop for groceries and run errands for the house. In addition, he has taken a second wife (in accord with his privileges pursuant to Islamic law) and has begun to pay less and less attention to both Ziba and their children.

Angry and humiliated, Ziba insists she must have permission for the divorce from her husband and without it cannot move on with her life. Ahmed says that he will not grant her request unless she forfeits her marriage dissolution payment and any other financial support for herself and agrees to give up custody of each child at age five. Ahmed says that by asking for a divorce, Ziba is demonstrating that she is an unfit mother and that his sons should thus revert to his care at the earlier age. Ahmed says that it is fitting that his sons should be taken into his care and raised by his female relatives.

At the mediation, Ziba capitulates and tearfully says she will waive all rights to financial support and agree to his requests regarding the transfer of custody at the given ages so long as Ahmed grants her request for a divorce. Although Ziba has agreed to relinquish her children two years earlier than traditional Islamic law would warrant, privately negotiated deviations from default rules are not uncommon. Ahmed is very unhappy with the prospect of divorce and strongly feels Ziba's behavior compromises her ability to parent. He has stated to you in private that the only reason he is not demanding immediate transfer is that he doesn't think Ziba will agree and doesn't believe he would receive support from his community. He is confident, however, that the agreement as contemplated is broadly supportable and within the norms of the Iranian community in which they live.

As mediator, do you help the parties with their divorce? 


\section{Comments on Case 12.2}

\section{Carrie Menkel-Meadow}

Whose culture? Whose laws? Whose ethics? Yours or mine?

Ziba and Ahmed's divorce mediation raises very difficult issues of cross-cultural mediation. My response to the dilemma presented here is easy for me, but likely to be seen as very controversial and unacceptable by many other mediators. I will explain why.

Self-determination (byboth the parties and the mediator), capacity and consent to any agreements, "true" understanding of possible alternatives, and my own legal and social justice concerns all militate against my deferring to the parties' claimed desire to use religious law and principles to resolve their dispute.

\section{SUITABILITY FOR MEDIATION? CLASH BETWEEN RELIGIOUS/COMMUNI-} TARIAN AND LEGAL SYSTEMS. Many ethnic, religious, and other affiliated communities have their own systems of rules, laws, and customs that they may seek to "enforce" through private mediation. Some have argued that mediation is particularly appropriate in such settings where communities seek to enhance their shared community values by their own systems of dispute resolution, away from the state or other cultures that they do not recognize or that do not recognize them (Freshman, 1997). If Ziba and Ahmed had contacted me with their desire to use Shari'a law, I would likely have made a referral to a specialized religion-based mediation center. I would not take their case. Here's why:

First, Ziba, now seventeen, has, according to the facts, been married for four years. That means she was thirteen when she married. The facts as given do not specify whether her marriage took place in the United States or in another country, but by no measure of "full faith and credit" would I regard a marriage made at thirteen to be a legal marriage in the United States. And wherever they live in the United States, a state court will have to finalize their "legal" divorce. Most states require evidence of a marriage certificate to certify the marriage when the divorce is judicially approved. A marriage certificate of a girl of thirteen would not be valid in virtually all states of the United States. Thus, in my view, the marriage is not "legal" under American domestic law (and American law is still required to make the divorce legally binding here) and legally could be annulled. In addition, it is also possible that, given the absence of 
a legal marriage, Ahmed might even be guilty of statutory rape under American law. Ziba could possibly file charges against him if she wanted to (or she might choose to use this information to prevent him from further abusing her or to "bargain" for her "rightful" financial and custody rights).

As a lawyer mediator with some experience in domestic relations (in litigation and in mediation), I would tell Ziba and Ahmed this together in a joint premediation session, as well as in any separate caucus that I would have with both parties. I would give legal advice and counsel to both of them at the same time and tell them what American law provides. I would, in the presence of both parties, tell Ziba that if she consulted an American lawyer, she would likely be entitled to financial support, as well as custody of both of her children. Other mediators might fear doing this because of possible domestic abuse or other negative actions that Ahmed might take when he sees his wife being so advised, but in my view, as long as she is living in the United States, she has the right to legal information according to the rules of this country.

WHOSE SELF-DETERMINATION? While I fully acknowledge all of our profession's norms and platitudes about self-determination (Standard I, Self-Determination, Model Standards of Conduct for Mediators, 2005), I do not believe that a thirteen-year-old girl had the capacity to "self-determine" when she married Ahmed, and thus the whole premise of the termination of the marriage is in question (for me). In addition, as long as we are looking at the platitudinous standards (which seldom help resolve really difficult questions), I would decline this case also for several other reasons:

- I am obviously not "impartial." I am judging the validity of the marriage and giving advice to one of the parties that at least one, if not both, of them is likely to view as "partial" (Standard II, Impartiality, Model Standards of Conduct for Mediators).

- I do not have the "competence" to mediate a case involving Shari'a law since I know not much about it, except as a legal educator and scholar. ${ }^{18} \mathrm{I}$ do know that its teachings are actually subject to much controversy, change, and interpretation, and I do not entirely trust what the parties tell me their mullah has told them (Abu-Odeh, 2006; Model Standards of Conduct for Mediators, Standard IV, Competence). 
- I do not believe that a mediation that would sanction or permit these results would be one with the requisite "quality of process" (Standard VI, Quality of the Process, Model Standards of Conduct for Mediators), which, in my view, requires "safety" of the parties (including the affected children), full presence and participation of the parties, party competency (including noninterference by third parties), and "mutual respect" among all participants.

- I have a conflict of interest (Standard III, Conflicts of Interest, Model Standards of Conduct for Mediators) because I have spent a great deal of my legal career as a feminist advocate for equality in marriage, self-determination, and the rights of women to no-fault divorce, as well as to adequate child and spousal support, and thus could not possibly be seen as neutral or impartial by Ahmed (and maybe by Ziba as well). In addition, I am committed in print (Menkel-Meadow, 2001), as well as in my practice, to tolerance and appreciation of diversity, in culture and religion, but I am a secular humanist, who, while acknowledging the importance of plural systems of law and culture, could not myself "preside" over a mediation that used a set of norms and customs that institutionalizes deep structures of inequality, even if seemingly "consented to."

I have turned down other cases in which parties are subject to deeply unfair or unequal rules or bargaining endowments (some cases of employment settings, some cases of unequal legal representation) or other matters where, in my view, mediation would lead to outcomes for which I would not want to be ethically responsible (Menkel-Meadow, 2004).

More complex issues actually underlie these "easy" answers from the Model Standards. One is that, as the hypothetical is intended to reveal, mediations like this pit significant cultural differences against each other: the couple's desire to use Shari'a law, which does not grant Ziba the same rights as domestic laws would, versus the mediator's own sense of legal entitlements and "justice." In cases of radically different cultural understandings, whose cultural understandings should govern? Isabelle Gunning has written eloquently on this point, in several relevant contexts, first in how "Western" feminists should deal with the religious or ethnic practice of "female 
genital mutilation" in the face of "international" standards of human health and safety (Gunning, 1991-1992, 1995) and, second, in seeing mediation as a site for self-empowerment for groups that are not recognized by or likely to be disadvantaged in formal court proceedings. The problem of cultural relativism or cultural hegemony is very significant in many modern mediations where parties choose to avoid formal law and legal systems and elect to apply other sources of social norms that they (and their mediators) may or may not share. There are no easy answers to the question of "whose culture" should govern.

PROCEED ON A BASIS OF DECLARED “SELF-DETERMINATION"? I suspect that many mediators would proceed with the mediation on the theory of party "self-determination," as long as they were comfortable with the conclusion that Ziba has "chosen" to be bound by Shari'a law. For these mediators, the cultural decision is for the parties, and as long as the parties "agree" on what cultural norms they want to apply to their dispute, the mediator's role is simply to ensure the process is fair and the agreement is freely consented to. In this case, some mediators might ask who am I to judge what these parties want; in the interest of self-determination, they have chosen to be governed by their own religious norms.

I could not, given my own "ethical culture" (Menkel-Meadow, 2001), act or be "complicit" in an agreement that I felt was legally, morally, or ethically wrong (and under these facts, I think all are true for me). Ziba did not knowingly consent to her marriage; she is dominated by Ahmed in the marriage and wants out so badly she is willing to bargain away her own maternity in order to be free of him.

Mediators have cultural and ethical commitments too, and in my view, no mediator (and certainly not this mediator) should participate in a mediation that she thinks will lead to a morally, legally, or ethically "unconscionable" result. What is unconscionable is, of course, subjective, personal, and nonuniversal. Thus, mediators must disclose their own relevant cultural, legal, personal, ethical, religious, political, or other commitments that will clearly affect how they facilitate dispute resolution.

One shorthand way to think about this is that the standards are for mediators too-and that includes self-determination. Mediators must also have the ability to determine when their "self" (including identity, integrity, professionalism, or other commitments) cannot be realized in a particular mediation. 
WHAT IF THE PARTIES DO NOT REALLY SHARE A CULTURAL UNDERSTANDING? As difficult as the above "cultural" issue is, there is even more difficulty if the parties themselves do not share cultural understandings or agreements about what norms to apply. Although not at issue as the hypothetical case is framed, suppose that early on or during the course of the mediation, it becomes clear that Ziba has actually been "coerced" into accepting Shari'a principles and, once informed of her rights under American domestic law, she would prefer to have those legal norms applied to her case. How mediators should "mediate" cultural differences between the parties in mediation is enormously complex. The norms by which mediation agreements are to be reached are often themselves the subject of negotiations and mediations, and mediators need to be able to mediate which norms will govern the mediation, even across cultural differences. Sometimes parties can agree on outcomes without explicitly acknowledging what principles got them there, but in general, where there is not some agreement about the governing norms or principles, the agreement may be in trouble if it requires enforcement, justification to third parties, or acceptability and legitimacy for the parties.

In this case, Shari'a law and American equitable distribution, community property, and no-fault divorce principles clearly conflict with each other, and if the parties cannot agree on what norms to apply to their divorce, mediation may not be the appropriate forum. In my view, a culturally competent mediator must at least raise with the parties what their differences are, what are the sources, cultural, religious, legal, or personal, of their differences, and offer sensitive conversations about how those differences might be handled. Of course, "cultural differences," like all other issues in mediation, may in fact differ in the eyes of the beholders, and different perceptions about whether there are in fact "cultural differences" may lead to an even deeper level of analysis, and disagreement (Gadlin, 1995).

THE RELEVANCE OF LAW. The astute reader of this commentary would have noticed that I have used legal analysis to locate my own cultural differences with the parties. "Under domestic/state/American law," Ziba would be entitled to no-fault divorce, possibly both child and spousal support, and certainly a legal right to pursue custody of her children. Thus, this mediator is using law to center (at least part of) her judgments about the case (and "judgments" they are). As 
I have controversially stated in other venues, mediation is often (and in this case would be) "the practice of law" (Menkel-Meadow, 1996). Even if the parties chose to be governed by Shari'a law, in the United States, a legal divorce must be approved by a state court, and thus American law is implicated in the decision. While it is now a controversy in many legal systems, including the United Kingdom, the United States, and Canada, about whether formal state courts should recognize Shari'a law in family law determinations, in the United States, Shari'a law has not yet been recognized in formal court determinations.

Every year in the United States, thousands (maybe even millions) of couples use private mediation, often with nonlawyer mediators who may be unfamiliar with applicable legal principles, using whatever principles they can agree on, to resolve issues of separation, financial support, child custody, and property division. In many, if not most, cases, if there is a settlement or private agreement, courts will approve the divorce in a general, pro forma (but legal) way and will not usually inquire into the equities of the parties' agreement unless an issue is raised formally with the court. There is no regular court review of private divorce agreements, even when the court must sign a formal decree of legal divorce. Nevertheless, family relations and status are still a matter of state law in the United States (indeed a very contested question of law, as the same-sex marriage political and legal battles make clear), and for me, in this case, as in all others I mediate, "the law is relevant, if not determinative" (Friedman \& Himmelstein, 2008). Thus, I will not mediate a case where there is relevant law for the parties to consider in evaluating their possible outcomes, rights, and alternatives, and the parties are unaware of those legal entitlements or endowments.

I would ask the parties here if they have discussed their legal rights with counsel, and if they have not, I would ask them if they would like referrals to do so. In this case, if $\mathrm{Ziba}$ and Ahmed said they were not interested in American law, I would tell them anyway (advising them together in joint session and then asking if they wanted to meet with me individually to discuss further).

For many mediators, this would be overstepping the boundaries of the mediator's "neutral" role, would involve the mediator in legal information provision or more accurately, legal advice giving, and would likely lead to the perception that the mediator was "partial" to one side (advising Ziba of what she could gain by pursuing American 
secular law). Yet for me, this legal advice and information would be absolutely essential for any determination I might want to make about whether the parties could in fact consent knowingly and willingly to an agreement under Shari'a law that eschewed legal entitlements that the parties might otherwise have.

Mediation is a process, not a separate justice system that automatically dismisses or renders inapposite "the law." At the same time, if a party is fully knowledgeable about the legal entitlements or arguments the law may provide, that party (indeed, both parties) may well decide to reach agreement or settle on the basis of other values (or nonlegal principles), seeking to apply his or her own sense of justice or fairness within his or her own relationship or community. Law or legal principles are not always determinative, and parties may and often do seek to do "real," if not "legal," justice between themselves. If, as a mediator, I am convinced they fully understand what they are doing, the parties may agree to depart from what the law might grant them. Laws are passed by legislatures for "the general public" and are interpreted by judges in particular situations. Mediation offers the parties a more democratic, nuanced, individualized, and self-empowering opportunity to interpret the law for themselves, as long as they agree and as long as the agreement is not legally voidable (by being unlawful).

However, as a lawyer mediator I will not participate in or "preside" over an agreement that is "unlawful" under applicable law. In this case, the secular law of divorce is still necessary to grant the parties a legal divorce in a state court of appropriate jurisdiction.

CONCLUSION. In this case, beyond the question of "whose culture" and "whose law" is the (for me) ethical question of "whose justice." Mediation is a process; it has no substantive commitments except knowing consent of the parties (and is backed up by the legal system's enforcement of legally acceptable contracts that can be enforced in courts) and an aspiration to do individualized and legitimate justice for the parties as they see it. For me, however, a mediator is also a party to a mediation, and thus the agreement that is reached must also be one that I can be accountable and responsible for as a participant in the process. My sense of ethics, culture, and yes, even justice is also at stake, for I am a party too.

I would honestly and completely tell the parties everything I have just told you, the reader, and would (1) advise them to seek legal 
advice and counsel about what is necessary for a legal divorce in my community; and (2) withdraw and ask them to find another mediator if they insist on applying a set of norms I am not competent to enforce, even as I have views about whether they do justice or not. This, of course, raises the next difficult issue of whether I am at all responsible for an outcome reached by someone other than myself (another mediator who agrees to let the parties use the agreement they have framed in the hypothetical, which you can see I think is unfair and unjust to Ziba). But that is a question for another day.

\section{Comments on Case 12.2}

\section{Harold Abramson}

The challenge posed by Ziba and Ahmed's divorce differs from difficulties customarily encountered in cross-cultural disputes. ${ }^{19}$ Often in domestic or international mediations, a cultural gap exists between the parties. But here the parties are culturally aligned, and the gap lies between the mediator and the parties.

The goal, as I see it, is clear: to ethically bridge the gap between the mediator and the parties while avoiding culturally imperialist behavior. No mediator wants to be charged with cultural imperialism when mediating private international disputes. And yet mediators run this risk whenever they resist doing what the parties want done. The challenge is to "give the parties what they want" without doing violence to universally held norms or one's own deeply held personal values.

For myself, after much soul searching, I decided that were I the mediator, I would go forward and assist Ziba and Ahmed in their efforts to conclude their divorce. But I reached that determination only after rejecting all the alternatives. Ziba and Ahmed don't afford a Western mediator any easy answers. All roads point toward moral discomfort. As difficult as this was, I tried to put my own personal values aside and look instead to see whether working with this couple would violate universally accepted international principles of human rights. My inquiries suggest that the answer is no; norms surrounding gender equity diverge dramatically throughout the world. This is one of the disturbing facts of multiculturalism, and as a mediator, I am wary of using my own personal views as the yardstick for how the parties should structure their affairs.

A second consideration influencing my decision flows from examining Ziba's other options. They didn't look promising to me. I 
thought by continuing to work with the couple, I could help them get the best deal possible. Contrary to the usual sunny rhetoric of win-win, here I would aspire toward "the least bad" outcome-an outcome that involves the least amount of moral violence and coercion for all involved. Here is how I got there.

THE CHALLENGE FOR THE MEDIATOR: A CROSS-CULTURAL DISPUTE. The thorny aspect of this cross-cultural conflict can be presented succinctly. Both parties agree broadly to a rule that, when they apply it, results in a mediated agreement that is unfair according to the mediator's Westernized values and may even violate Western domestic law.

Consider the way Ahmed's power over granting a divorce was being used to extort a one-sided agreement, at least from a Westernized point of view. A Western mediator would likely view as unfair an agreement where unemployed Ziba waives needed financial support and relinquishes rights to her children once they turn five. Under Westernized common law and statutory laws, such a one-sided agreement also is likely to be invalid and unenforceable due to Ahmed's extortionate behavior and the duress suffered by Ziba who wants the divorce. ${ }^{20}$

This culturally shaped family mediation starkly raises an old issue in new packaging: Should a mediator withdraw when the mediator encounters a rule, practice, or emerging agreement that the mediator thinks is unfair? In this dispute, the new packaging entails an objectionable foreign cultural rule and its impact on the resulting mediated agreement. Without this cultural overlay shaping the parties' behavior and resulting agreement, I suspect that many Western mediators would withdraw from the mediation. With the cultural overlay, however, it is less clear what a mediator ought to do.

A FOUR-STEP APPROACH. Cross-cultural mediators live under the constant threat of being charged with cultural imperialism. Mediators do not want to be guilty of parochial ignorance and arrogance when objecting to what might be a cultural practice. They want to avoid claiming that they are right and the parties wrong. In order to reduce this risk, cross-cultural mediators should approach mediations with a healthy respect for cultural pluralism and a clear understanding of the other cultural practice. 
In analyzing what a mediator might do in this case, I will follow the four-step approach that the editor of this book introduced on my behalf at the outset of the chapter. This sequence is designed to guide mediators along an ethical path that can also help to avoid the cultural imperialist charge. The mediator should:

\section{Understand his or her own cultural practices}

2. Research the other cultural practice to be sure that the mediator understands its terms and its rationale

3. Bridge any cultural gap between the mediator and parties by posing questions to the parties to be sure that the parties are making informed, voluntary, and uncoerced decisions

4. Withdraw if the mediator concludes that the practice violates an internationally recognized norm or compromises the mediator's impartiality or the mediation process

Understand One's Own Culture. Consciously or not, mediators inescapably read a dispute through their own culturally shaped lens. Consequently, they need to develop a degree of cultural competency and self-awareness in order to distinguish universal behavior from their own cultural views. Developing this self-awareness requires doing some research. I have found it helpful to read articles and books that compare communication in different cultures and describe U.S. culture for foreigners; it is especially fascinating to learn how others view one's own culture. For mediator ethics in the United States, the Model Standards of Conduct for Mediators provide the primary cultural lens through which mediators see their disputes. So I began this journey by reacquainting myself with the Model Standards and especially the values that they reflect.

As discussed in Chapter Five in this book, the Model Standards do not hold mediators accountable for the substantive fairness of the mediation agreements they help orchestrate. Rather, they require mediators to focus on process fairness and assume that when process fairness is ensured, substantive fairness will follow. To this end, the Standards require mediators to foster party self-determination and competency, mediator impartiality, and scrupulousness of process. But they steer clear of discussions of fairness, equity, and substantive justice. $^{21}$ 
The code reflects the mediation culture in the United States: a studiously process-oriented culture that exempts mediators from the burden of judging the fairness of the parties' desired outcome. Still, while mediators need not subject proposed agreements to a fairness litmus test, principles of party self-determination, impartiality, and quality process still offer much for mediators to ponder, as this hypothetical illustrates.

A mediator might view Ziba's custody and financial giveaways as so problematic as to call into question the likelihood that she is acting voluntarily, consistent with the mandate of self-determination. The one-sidedness may tug at the mediator's sympathies, causing the mediator to ally with Ziba and creating partiality. In the face of these types of problems, the Model Standards instruct the mediator to "take appropriate steps including ... withdrawing from or terminating the mediation."

Therefore, ample justification exists for a mediator to consider withdrawing. But in a dispute laden with non-Westernized practices and behavior, the mediator should take additional steps before deciding whether to withdraw. The mediator needs to research the other culture and try to bridge any cultural gaps. These additional steps are essential if the mediator wants to avoid the charge of cultural imperialism.

Research the Other Culture. A mediator cannot help bridge a cultural gap without learning and understanding the cultural practices of the parties. Sources may be difficult to locate, and their messages recondite and conflicting. Still, the mediator needs to endeavor to become acquainted with the terms of a cultural practice as well as its rationale. The inquiry may be discomfiting because the relevant practice may seem abhorrent to a mediator of a certain background and upbringing. However, the inquiry is crucial, and the mediator must be open to the possibility that an offensive practice may turn out to be tolerable when understood in context.

For example, ${ }^{22}$ seeking to understand a practice of arranged marriages involving payment may seem offensive. After all, the practice was condemned in the United Nations Report of the Committee on the Elimination of Discrimination Against Women. ${ }^{23}$ Why seek to understand this approach to women and family? Because you might find it helpful to learn one commentator's justification for the practice: "The payment of mahr (dower), which involves payment or 
preferment, is a central feature of the marriage contract in Islam and, as a measure intended to safeguard [a woman's] economic position after marriage [the mahr is offered to the bride]."

It may feel equally repugnant to remain open to a practice that gives men a right to a greater share of property, a practice also apparently condemned in the Convention on the Elimination of All Forms of Discrimination Against Women (Article 16[h]). But you might find it helpful to hear the same commentator's explanation on this point: in Islam, men have financial obligations to others that are not shared with women, so men need a disproportionate amount of assets to meet those other obligations. Of course, neither this nor the earlier rationale provides the final word, but they do offer leads on further research that a mediator might want to pursue.

For this hypothetical case, a mediator would need to learn the cultural explanation for a practice that confers on Ahmed the exclusive power over approving a divorce and therefore the potential to extract a one-sided divorce settlement.

My preliminary research uncovered some initial insights. ${ }^{24}$ The Egyptian government, in commentary on an international treaty relating to women's rights, explained that the restrictions placed on women's ability to terminate marriage are designed to balance out their rights to full financial support within the marriage and the payout they receive at the marriage's end. That is, according to Shari'a, women enter into marriage free of any requirements to contribute financially but then must yield to male preferences regarding how long or whether the marriage is to endure. In short, Shari'a aims toward symmetry, balance, and equality between the sexes, although Westerners may not be comfortable or agree with the manner in which burdens and benefits are distributed.

Bridge Any Cultural Gaps. With some understanding of the cultural context of the practice, the mediator is ready to proceed with a sophisticated self-determination inquiry. As a threshold matter, I assume that the parties have legal counsel. I also assume that the parties were encouraged to seek counsel from a trusted family member or friend so that each party has the benefit of a support system that each party trusts.

As the mediator here, I would give Ahmed and Ziba an opportunity to express their reactions to the rule and consider its rationale, benefits, and drawbacks. Then I might follow up with clarifying and 
reality-testing questions. This is not a simple inquiry, and of course it is often easier to describe what to do than to actually do it. But it is an essential inquiry if mediators want to seriously pursue party self-determination. One of two basic scenarios might emerge: Ziba accepts the rule or she objects to it.

Under the first scenario, in which Ziba accepts the rule, if she does so understanding the disadvantageous trade-offs that it can produce when dissolving the marriage, at least she is making an informed choice to live with its consequences. Her formal acceptance under these circumstances, however, should not go uninspected. It is important to inquire into the circumstances surrounding the "choice" to accept. As critics of cultural pluralism point out, the term choice connotes options: "It is one thing to embrace a way of life when none other is available, an entirely different one to cling to it when alternatives present themselves." 25

Therefore, I would test her acceptance by tempting her with options. For example, Ziba does have an alternative if the mediation is taking place in New York State, which has a state law designed to diminish the ability of a husband to extort an unduly favorable settlement under a religious rule that gives the power to divorce to the husband. ${ }^{26}$ The mediator might inquire whether the parties or attorneys are aware of the applicable law. Through their attorneys, the parties would learn that New York law authorizes a court to consider whether Ahmed exploited a barrier to remarriage when the court determines the distribution of marital property and appropriate maintenance. Therefore, Ziba would have an option for ameliorating the influence of the rule and a choice to make. She could agree to Ahmed's onerous demands. But she could also turn to or threaten to turn to the secular courts to reduce her unequal bargaining power. This may not seem like a real choice for someone who wants to preserve her standing in her own religious community. But it gives Ziba an opportunity to choose which value is more important to her: preserving her standing in her community or improving the terms of divorce.

I found this part of my deliberations unsettling because it seemed disconcertingly easy to justify Ziba's rights waivers by casting them as deliberate demonstrations of her idiosyncratic will. Having knowingly accepted the rule and chosen to follow it, Ziba would probably continue to pursue the religious divorce regardless of the alternatives the secular courts might offer. This substantive result may be unfair 
by Westernized standards, but not necessarily unfair based on the values Ziba adopted. My limited role as a mediator who perseveres to honor the principle of party self-determination becomes clear in this situation. In the end, all mediators can do is conduct a process where the parties can make an informed choice, regardless of how personally painful the choice may be to one of the parties and how unfair the result may seem to the mediator.

The second scenario is that Ziba-albeit perhaps a dedicated member of her religious community-objects to its rule and its consequences. In that case, the conflict of values between her and the mediator disappears. Then the mediator can no longer be accused of imposing his or her own values on the parties, since one of the parties now asserts those values. With this agreement, Ziba effectively shields the mediator from the charge of cultural imperialism, although not from the charge of partiality. The mediator no longer needs to bridge a cultural conflict between the mediator and the parties. The mediator can now return to the familiar territory of trying to bridge a gap between the parties.

Withdraw? Even in the face of the parties' consent or apparent consent, the mediator may still find the agreement so personally abhorrent as to want to withdraw. But how can a mediator withdraw and avoid the charge of cultural imperialism?

Walking this tightrope requires attention to two inquiries. First, does the cultural practice violate internationally recognized norms? Second, even if it doesn't, is it possible to remain impartial when intensely disapproving of the norms the parties are embracing?

My search for universal international norms relating to Ziba and Ahmed's case led me to scrutinize international treaties touching on the rights of men and women in the domestic sphere. If most countries, including Iran and surrounding nations, had ratified these treaties, then I could comfortably conclude that the norm of gender equality was universally recognized, even by the countries to which Ziba and Ahmed were culturally aligned. Unfortunately, I found no such universal agreement.

The United Nations General Assembly has adopted two statements: the Convention on the Elimination of All Forms of Discrimination Against Women and the Universal Declaration of Human Rights. Both declare in ringing language that men and women have equal rights in marriage and its dissolution. But when I checked the 
fine print, I discovered that Iran has never ratified the Convention, and the Universal Declaration was simply enabling legislation that did not require endorsement or acceptance of any sort. Even worse, many Middle Eastern countries, including Iran's close neighbors, took explicit exception to the convention's gender equality language, opting out of those provisions that violated "norms of Islamic law" or were "incompatible with the provisions of the Islamic Shari'a."

Rather than unanimity in the realm of gender equality, I found disarray. My forays into international law revealed no principled source of internationally recognized standards that could be the basis for withdrawing from the mediation. Different cultures view women's rights to enter into and exit marriage differently. Given this (discomfiting) fact, I pondered whether there was any other principled basis for withdrawing - specifically the second inquiry about my ability to remain both impartial and intensely disapproving of the norms the parties were embracing.

Obviously if I found myself hopelessly partial-biased against Ahmed - then withdrawal would be appropriate. Standard II of the U.S. Model Standards requires mediators to maintain impartiality, and if my feelings about Ahmed's demands eliminate my ability to respond evenhandedly, then I should not continue. Standard VI's discussion of a "quality process" may also be implicated. Of course, if my decision to withdraw is based on my own cultural value, then I might remain vulnerable to the ultimate charge of cultural imperialism - the charge that I'm claiming "my culture is better than your culture."

Despite my desire to be respectful toward Ziba and Ahmed's claimed cultural stance, withdrawal was the direction I was going in until my research assistant innocently asked about next steps: "Would what would happen after withdrawal be better than the mediator continuing?" she inquired. What would Ahmed and Ziba's BATNA (best alternative to a negotiated agreement) be if the negotiation in the mediation were prematurely halted? This inquiry prompted me to consider Ziba's opportunities without mediation. What if no fairer venue exists for her? In that case, depriving her of the mediation opportunity contributes to her disadvantage. If I withdraw, Ziba loses access to help by a third party with expertise in dispute resolution, who might be culturally sensitive to this unequal power dynamic and might be able to help her negotiate further details within the parameters of the agreement. If I continue 
with the mediation, on the other hand, I might be able to help Ahmed and Ziba negotiate valuable details that might benefit the children, including addressing such issues as visitation and education plans.

This was the most difficult decision moment for me. After trying to research Ziba's BATNA and much cogitating, ${ }^{27}$ I thought I still would withdraw if faced with this dilemma. I would not want the mediation process (or me) to be associated with such an unfair mediated result. I would want to avoid conferring the imprimatur of mediation on a process and result that violated such a core value of fairness, even when my definition of fairness was shaped by distinctively Westernized values. This was my conclusion until I realized that I was so determined to withdraw that I had become blinded to the significant benefits of continuing for the parties. I am now inclined to continue to mediate. ${ }^{28}$ If both parties want to continue with me and the mediation, I think I should try to mediate the best agreement the parties are willing to enter into, so long as the agreement is not illegal.

CONCLusion. When crossing borders, mediators are crossing into new ethical territory. Ethical issues can arise due to differences in culture between the mediator and the parties. In order to navigate this new territory, mediators need to be aware of their own culturally shaped behavior and perspective and be open-minded and nonjudgmental when learning about other ways of behaving. And mediators should diligently search for ways to bridge any gaps between the mediator and the parties before confronting the difficult possibility of withdrawing. By conscientiously following the steps outlined in these comments, mediators should be able to avoid the charge of cultural imperialism, except when they consciously decide to be imperialistic.

\section{Editor's Thoughts on Case 12.2 and the Comments}

Both Abramson and Menkel-Meadow acknowledge the difficulty of this case and come to dramatically different conclusions regarding what they would do. Although superficially it seems as if they "went to the same movie theater but saw a different show," a closer look reveals their analyses to be more similar than initially apparent. 
First, both Abramson and Menkel-Meadow note that the Model Standards provide ample justification for withdrawal. Both make reference to the provisions regarding impartiality and ensuring a quality process and note that their discomfort with Ziba's anguished rights waivers would call into question their ability to proceed on these grounds. At the same time, both commentators note that the Standards beg the larger questions of how mediator partiality to familiar (in this case, Western) norms can be ethically squared with multicultural practice and whether the primary self-determination commandment takes adequate account of the coercive environments in which disputants may be situated.

Both Abramson and Menkel-Meadow note that many mediators would proceed on the grounds that the parties have chosen the governing norms and that respect for party self-determination justifies mediator acquiescence to that choice. However, Abramson questions whether choice in the absence of adequate options passes muster, and Menkel-Meadow affirmatively denies that Ziba's financial and custody giveaways could be viewed as "freely chosen," even when measured by the "thinnest" notions of self-determination's requirements.

Though discomfited by Ziba's predicament, Abramson states that he would proceed with the case, while Menkel-Meadow maintains that she would have to turn it away. Each of these thoughtful mediator scholars reaches a fork in the road where a singular path calls. In assessing the road to take and the road not taken, they are prodded by different visions of mediator autonomy in the process.

For Menkel-Meadow, one primary consideration appears salient. She believes that the opportunity for self-determination exists for mediators as well as parties. Mediators hew to a moral code that guides their everyday thoughts and actions. Just as mediation offers parties an opportunity to express their deepest normative commitments, so too must the process respect and give voice to mediator values. Abramson takes a more self-abnegating view. He holds that mediators should strive to avoid withdrawal or termination based solely on their own personal assessment of the parties' values. Rather, withdrawal can be justified only when grounded in the parties' rejection of universally held international norms. If what the parties are inclined to do violates a United Nations proclamation or a treaty to which the majority of the world is a signatory, then withdrawal is amply justified. If it simply makes the individual mediator queasy, withdrawal is suspect. 
Given Abramson's inclination to stifle his visceral offense and consider Ziba and Ahmed's options, it is perhaps not surprising that he comes to the conclusion that he, and mediation, can produce a happier outcome than would likely be achieved in a different forum. Abramson takes a dim view of Ziba's BATNA and so decides that the most ethical course is to hang in there and see if he can help bring about as salutary a conclusion to the marriage as is possible under the circumstances. Menkel-Meadow says that if she played any role with the couple, she would discuss with them Ziba's entitlements under American law and would then refer the case to someone whose "ethical culture" did not recoil against the structural inequities built into the Shari'a law that both Ziba and Ahmed honor. MenkelMeadow notes that ethical issues attach to the question of whether she is at all responsible for an outcome that another mediator facilitates but concludes, "That is a question for another day."

\section{References for Carrie Menkel-Meadow's Comments}

Abu-Odeh, L. (2006). Family law reforms: The central Arab states. In

S. Joseph (Ed.), Encyclopedia of women in Islamic cultures. Leiden: Brill.

Freshman, C. (1997). Privatizing same-sex marriage through alternative dispute resolution: Community enhancing versus community enabling mediation. UCLA Law Review, 44, 1687.

Friedman, G., \& Himmelstein, J. (2008). Challenging conflict: Mediation through understanding. Chicago: ABA Press.

Gadlin, H. (1995). Conflict resolution, cultural differences and the culture of racism. Negotiation Journal, 33, 35.

Gunning, I. (1991-1992). Arrogant perception, world traveling and multicultural feminism: The case of female genital surgeries. Columbia Human Rights Law Review, 23(4), 189-248.

Gunning, I. (1995). Diversity issues in mediation: Controlling negative cultural myths. Dispute Resolution Journal, 1, 55-93.

Menkel-Meadow, C. (1996). Is mediation the practice of law? Alternatives to the High Cost of Litigation, 14, 57.

Menkel-Meadow, C. (2001). And now a word about secular humanism, spirituality and the practice of justice in conflict resolution. Fordham Urban Law Journal, 28, 1073.

Menkel-Meadow, C. (2004). What's fair in negotiation? What is ethics in negotiation? In C. Menkel-Meadow \& M. Wheeler (Eds.), What's fair: Ethics for negotiators. San Francisco: Jossey-Bass. 